Journal of Economics, Finance and Accounting Studies (JEFAS)

ISSN: 2709-0809

DOI: $10.32996 /$ jefas

Journal Homepage: www.al-kindipublisher.com/index.php/jefas

\title{
The Influence of Investment, Liquidity and Profitability on Dividend Payout Ratio Policies of the 2015-2019 Indonesia Stock Exchange Listed LQ-45 Companies
}

\author{
Siti Mujiatun ${ }^{1}$, Rosita$^{2}$ and Sunday Ade Sitorus ${ }^{3} \square$ \\ ${ }^{1}$ Universitas Muhammadiyah Sumatera Utara, Indonesia \\ ${ }^{2}$ Institut Teknologi dan Bisnis IT \& B, Indonesia \\ ${ }^{3}$ STIE ITMI Medan, Indonesia
}

$\square$ Corresponding Author: Sunday Ade Sitorus, E-mail: sundayadecoms@gmail.com

\begin{abstract}
ARTICLE INFORMATION
Received: 08 September 2021

Accepted: 04 October 2021

Published: 26 October 2021

DOI: $10.32996 /$ jefas.2021.3.2.12

\section{KEYWORDS}

Investment, Liquidity, Profitability,

Dividend Payout Ratio Policies.

\section{ABSTRACT}

Dividend policies aim to determine the number of dividends to shareholders and the amount to be reinvested (retained earnings). In this study, dividend policies were measured using the Dividend Payout Ratio (DPR). This study aimed to test and analyze the influence of investment, liquidity, and profitability on dividend payout ratio policies of the 2015-2019 Indonesia Stock Exchange Listed LQ-45 companies. The purpose is to find out and examine the pattern of Investment, Liquidity, and Profitability in the Dividend Payout Ratio Policy of Companies listed on LQ-45 Indonesia Stock Exchange 2015-2019. The subjects of this study were the Indonesia Stock Exchange Listed LQ-45 companies while the objects were the 2015-2019 financial statements. The population of this study was 45 companies with 30 companies as the samples after purposive sampling. Data were analyzed using multiple linear regression, classical assumption test, and hypothesis testing. The results of research in partially, investment and profitability had a significant and positive influence on the dividend payout ratio policies while liquidity had no influence on the dividend payout ratio policies. Simultaneously, investment, liquidity, and profitability had an $11.8 \%$ influence on the dividend payout ratio policies while the remaining $88.2 \%$ were explained by other variables such as leverage ratio, growth, and others.
\end{abstract}

\section{Introduction}

The capital market plays an important role in encouraging initial public offering companies to further improve the performance of companies, one of which is by announcing profits and dividends paid to shareholders. LQ45 companies are the most liquid companies on the Indonesia Stock Exchange. LQ45 can be an appeal for investors in measuring the dividend policies of companies. Dividend policies are an integral part of funding decisions. Dividend policies aim to determine the number of dividends to shareholders and the number to be reinvested (retained earnings). In this study, dividend policies were measured using the Dividend Payout Ratio (DPR). The dividend payout ratio determines the retained earnings in companies as a source of funding. If companies decide to divide earnings as dividends, it means reducing the amount of retained earnings, thus reducing the source of funds that will be used to develop the companies. Conversely, if companies do not pay profits as dividends, it will have an impact on investors, where dividends are one of the attractions for investors. Investment opportunities aim to increase growth companies in which companies tend to use funds from internal sources because they are preferred to finance reinvestment activities with lower risks and costs. Investment opportunities can affect dividends received by shareholders. Liquidity has a huge influence on investment and funding fulfillment policies. Dividend for companies is a cash-out, so the greater the overall cash position and liquidity, the greater the ability to pay dividends. Profitability is the ability of companies to generate profits sales, total assets, and their own capital. In this study, profitability was proxies against Return on Assets (ROA). The following is the data of the three companies incorporated in LQ 45 to illustrate the problem.

Copyright: (C) 2021 the Author(s). This article is an open access article distributed under the terms and conditions of the Creative Commons Attribution (CC-BY) 4.0 license (https://creativecommons.org/licenses/by/4.0/). Published by Al-Kindi Centre for Research and Development, London, United Kingdom. 
Table 1. LQ 45 Companies Data

\begin{tabular}{|c|c|c|c|c|c|}
\hline Companies & Year & $\begin{array}{l}\text { Investment } \\
\text { (unit) }\end{array}$ & $\begin{array}{l}\text { Liquidity } \\
\text { (Times) }\end{array}$ & $\begin{array}{l}\text { Profitability } \\
\text { (\%) }\end{array}$ & $\begin{array}{l}\text { Dividend } \\
\text { Policies (\%) }\end{array}$ \\
\hline \multirow[t]{5}{*}{ Adaro Energy Tbk } & 2015 & 353.720 & 2.404 & 2.534 & 51.461 \\
\hline & 2016 & 1935.220 & 2.471 & 5.223 & 47.245 \\
\hline & 2017 & 1964.919 & 2.559 & 7.872 & 19.035 \\
\hline & 2018 & 1309.020 & 1.960 & 6.763 & 63.306 \\
\hline & 2019 & 1734.219 & 1.712 & 6.027 & 50.296 \\
\hline \multirow[t]{5}{*}{ AKR Corporindo Tbk } & 2015 & 3.889 & 1.496 & 6.964 & 48.390 \\
\hline & 2016 & 2.966 & 1.271 & 6.613 & 34.305 \\
\hline & 2017 & 2.817 & 1.624 & 7.755 & 45.993 \\
\hline & 2018 & 1.735 & 1.398 & 8.007 & 55.318 \\
\hline & 2019 & 1.575 & 1.237 & 3.284 & 102.783 \\
\hline \multirow[t]{5}{*}{ Astra International Tbk } & 2015 & 1.920 & 1.379 & 6.361 & 67.796 \\
\hline & 2016 & 2.394 & 1.239 & 6.989 & 44.476 \\
\hline & 2017 & 2.149 & 1.229 & 7.835 & 37.069 \\
\hline & 2018 & 1.910 & 1.126 & 7.941 & 37.253 \\
\hline & 2019 & 1.501 & 1.291 & 7.564 & 42.185 \\
\hline
\end{tabular}

Source: Indonesia Stock Exchange, 2020

Based on the data above, if an increase in investment is not followed by a decrease in dividend policies, an increase in liquidity and profitability is not always followed by an increase in dividend policies. In addition to the phenomena based on the above data, management often has difficulty deciding whether to pay dividends to investors or to hold profits for reinvestment. Even though companies have relatively large amounts of cash, companies do not only allocate a large number of funds in dividend payments but also in investment, differences in interests between managers and shareholders can cause problems in dividend payout, where companies with good liquidity do not necessarily allocate a large number of funds to pay dividends. The purpose of the research is to find out and examine the pattern of Investment, Liquidity, and Profitability in the Dividend Payout Ratio Policy of Companies listed on LQ-45 Indonesia Stock Exchange 2015-2019. Based on this background, researchers had the interest to conduct a study entitled "The Influence of Investment, Liquidity, and Profitability on Dividend Payout Ratio Policies of The 2015-2019 Indonesia Stock Exchange Listed LQ-45 Companies".

\section{Literature Review}

\subsection{Investment}

The investment aims to increase growth in companies in which companies prefer to use internal sources of funds because they are preferred to finance reinvestment activities with low risk and cost.

Rambe et al. (2015: 21), point out that the investment function includes managing funds into assets to achieve goals, including achieving new investment projects to maximize goals. According to Mulyawan (2015: 260) states "the bigger the investment opportunities, the fewer dividends paid. It is better if invested funds generate a positive NPV."

\subsection{Liquidity}

Liquidity is the ability to fulfill daily internal operational needs. Prihadi (2019: 202), states that liquidity is the ability to pay off current liabilities. Short-term liabilities or current debt are debts paid off within one year. Liquidity is very basic for companies. In daily routine, liquidity will be reflected in the ability to pay creditors on time or pay salaries on time. The measurement of liquidity usually associates current liabilities with current assets available to pay off. Measurements can include all current assets or a portion 
of current assets. Murhadi (2018: 57), states that "the liquidity ratio shows the ability to meet current liabilities." Kariyoto (2017: 190), argues that the calculation of liquidity is certainly inseparable from the influencing factors, namely: Cash and bank, Marketable securities, Account receivable, Inventory, Prepaid expenses

\subsection{Profitability}

The profitability ratio shows the performance of the company in generating profits using resources. In fundamental analysis, the profitability ratio is a very important comparison because if a company is not able to generate promising profits, investors will be reluctant to invest in the company. Prihadi (2019: 166), points out that profitability is the ability to generate profits. The definition of profit can vary, depending on the needs for measuring the profit. Kariyoto (2017: 114), states that the profitability ratio is a ratio to measure the company's ability to benefit from its capital. The profit ratio can be measured by several indicators, namely:

1. Profit margin

Profit margin is the company's ability to generate profits compared to sales achieved. The ratios that can be used are as follows :

Gross Profit Margin = gross profit $\times 100 \%$

Sales

Profit Margin $=$ EAT x $100 \%$

Sales

Net Profit Margin = EBIT $\times 100 \%$

Sales

2. Return on Asset

Return on assets is often referred to as economic profitability as a measure of the company's ability to generate profits with all assets owned.

$$
\text { Return on Asset }=\underline{\mathrm{EBIT}} \times 100 \%
$$

Total assets

3. Return on Equity

Return on Equity often called the rate of return on net worth is a measure of the company's ability to earn profits with the owner's equity.

Return on Equity = EAT $\times 100 \%$

Owner's equity

4. Return on Investment

Return on Investment is a measure of companies to obtain profits to pay off their investments.

Return on Investment $=$ EAT $\times 100 \%$

Investment

5. Earning Per Share

Earning Per Share is a measure of the company's ability to generate earnings per share of the owners.

$$
\text { EPS }=\frac{\text { EAT }}{\text { Number of Shares }}
$$




\subsection{Dividend Payout Ratio Policies}

The dividend payout ratio is the percentage of every rupiah generated to be distributed to owners in cash. It is calculated by dividing dividends per share by earning per share. Mulyawan's (2015: 253), dividend policies show the decision to share profits earned to shareholders as dividends or to hold in the form of retained earnings to be used as investment financing in the future. Sudana (2015:26) shows the dividend payout ratio as follows :

\begin{tabular}{|l|l|}
\hline Dividend Payout Ratio $(\mathrm{DPR})=$ & Dividend \\
& Earning after taxes \\
\hline
\end{tabular}

\subsection{The Framework of research}

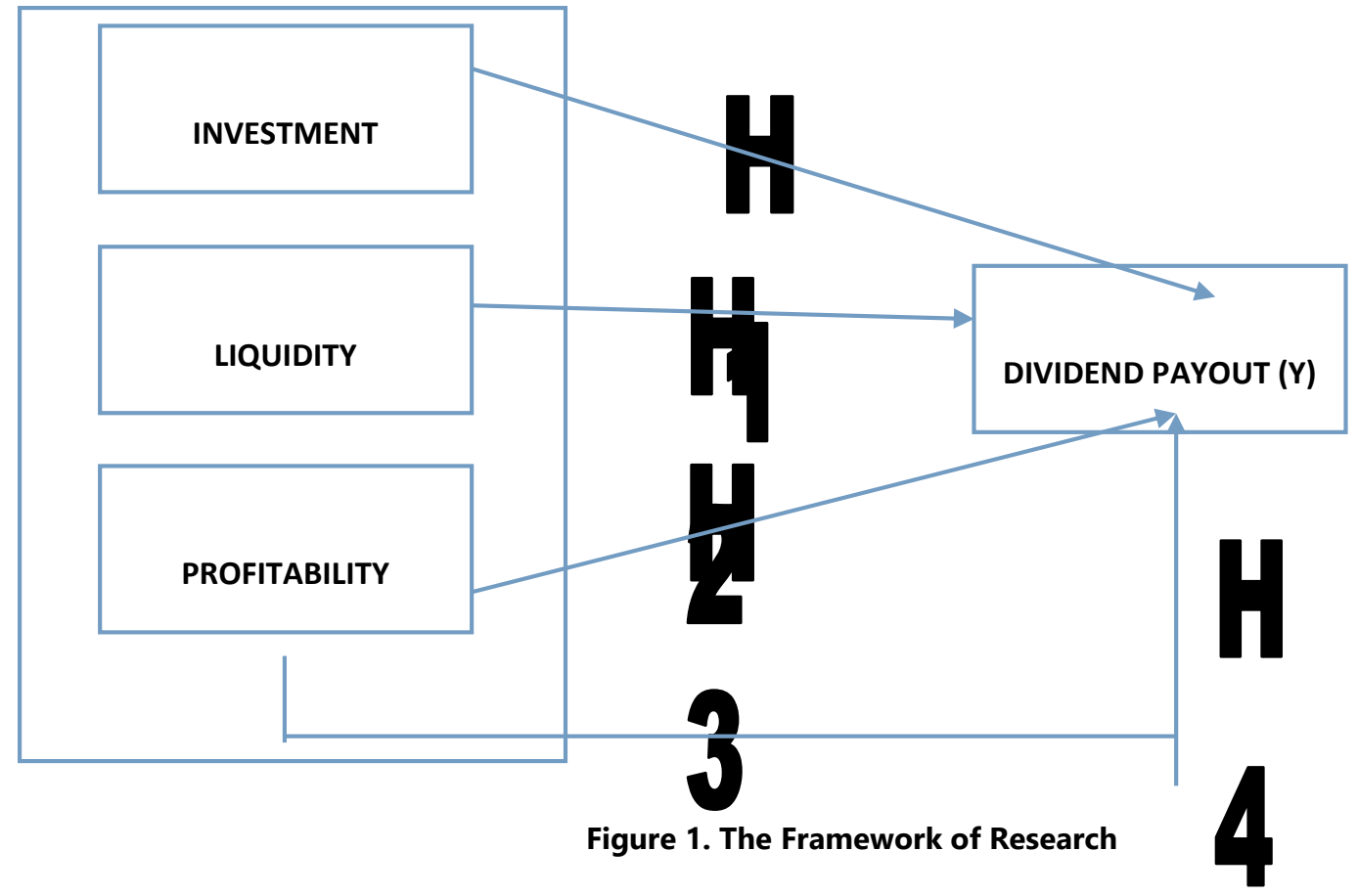

\section{Method}

The subjects of this study were the Indonesia Stock Exchange Listed LQ-45 companies while the objects were the 2015-2019 financial statements.

\subsection{Population and Sample}

In this study, the population of this study was 45 Indonesia Stock Exchange Listed LQ-45 companies. This study used purposive sampling. Sugiyono (2017), "Purposive sampling is a sampling technique with certain considerations."

Table 2. Sampling

\begin{tabular}{|l|l|l|}
\hline No & Description & Total \\
\hline 1. & IDX listed LQ-45 Companies & 45 \\
\hline 2. & LQ-45 Companies without positive net income for 2015-2019 consecutively & $(4)$ \\
\hline 3. & LQ-45 Companies without a dividend for 2015-2019 consecutively & $(4)$ \\
\hline 4. & LQ-45 Companies without liquidity data for 2015-2019 consecutively & $(7)$ \\
\hline & Number of samples & $\mathbf{3 0}$ \\
\hline & Number of periods & $\mathbf{5}$ \\
\hline & Number of observations $=\mathbf{3 0} \mathbf{5}$ & $\mathbf{1 5 0}$ \\
\hline
\end{tabular}

Source: Own Calculated, 2021 


\subsection{Operational Definition of Variables.}

Table 3. Operational Definition fo Variables

\begin{tabular}{|c|c|c|c|}
\hline Variable & Definition & Indicator & Scale \\
\hline Investment $\left(\mathrm{X}_{1}\right)$ & $\begin{array}{l}\text { Investment is an effort carried out by reducing } \\
\text { consumption in the present to generate future } \\
\text { returns for investors. } \\
\text { Source: Sulaiman and Sumani (2016:179) }\end{array}$ & $\begin{array}{l}\text { Market to book ratio }= \\
\frac{\text { Market per share }}{\text { Book value per share }} \\
\text { Source: Sudana }(2015: 27)\end{array}$ & Ratio \\
\hline Liquidity $\left(\mathrm{X}_{2}\right)$ & $\begin{array}{l}\text { The liquidity ratio describes a company's } \\
\text { ability to settle current liabilities } \\
\text { Source: Harahap (2016:301) }\end{array}$ & $\begin{array}{l}\text { Current Ratio }= \\
\text { Current Asset } \\
\text { Current Liabilities } \\
\text { Source: Sudana (2015:24) }\end{array}$ & Ratio \\
\hline $\begin{array}{l}\text { Profitability } \\
\left(X_{3}\right)\end{array}$ & $\begin{array}{l}\text { The profitability ratio assesses a company's } \\
\text { ability to seek profits } \\
\text { Source: Kasmir (2015:196) }\end{array}$ & $\begin{array}{l}\text { Return on Asset }= \\
\frac{\text { Earning After Taxes }}{\text { Total Assets }} \\
\text { Source: Sudana }(2015: 25)\end{array}$ & Ratio \\
\hline $\begin{array}{l}\text { DPR Policies } \\
(Y)\end{array}$ & $\begin{array}{l}\text { The cash dividend payout ratio shows the } \\
\text { percentage of net income in the form of cash } \\
\text { dividends to shareholders } \\
\text { Source: Hery }(2017: 87)\end{array}$ & $\begin{array}{l}\text { Dividend Payout Ratio = } \\
\text { Dividend } \\
\text { Earning After Taxes } \\
\text { Source: Sudana (2015:26) }\end{array}$ & Ratio \\
\hline
\end{tabular}

\subsection{Data Analysis Technique}

This study used multiple linear regression and hypothesis testing using Statistical Packages for the Social Science (SPSS) version 25.00. The multiple linear regression equation is:

$Y=a+b_{1} X_{1}+b_{2} X_{2}+b_{3} X_{3}+e$

\section{Results and Discussion}

\subsection{Results}

The classical assumption test results met the classical assumption requirements, namely normality test, multicollinearity test, autocorrelation test, and heteroscedasticity test. The classical assumption test results can be seen as follows.

\subsubsection{Normality Test Before Transformation}

The normality test aims to test whether, in the regression model, the residual variables have a normal distribution. Normal residuals can be analyzed graphically on a histogram by comparing the observed data with a distribution close to normal and a normal probability plot by comparing the cumulative distribution of the normal distribution. 


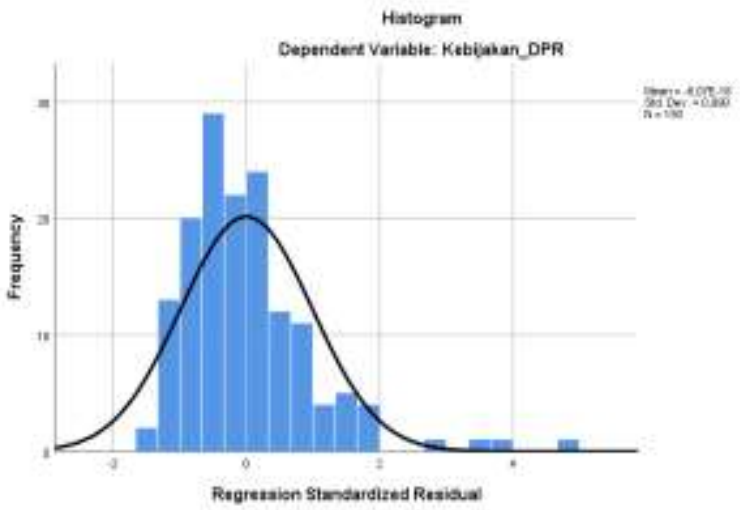

Figure 1. Histogram Normality Test Before Transformation

Source: Processed Data, 2020

Based on the figure above, the curve lines are not symmetrical, so it can be said that the data were not normally distributed.

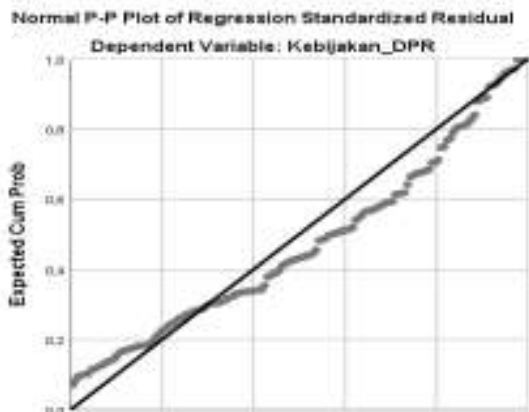

Figure 2. P-P Plot Normality Test Before Transformation

Source: Processed Data, 2020

Based on the P-P Plot Normality Test graph, some of the points do not spread around the diagonal line, so it can be said that the data were not normally distributed. In addition to using graphs, to find out whether the data are normally distributed, the Kolmogorov Smirnov non-parametric statistical test can be used, where if the significance level> 0.05 , the data are normally distributed.

Table 4. The Kolmogorov Smirnov Normality Test Before Transformation

\section{One-Sample Kolmogorov-Smirnov Test}

\begin{tabular}{lll}
\hline N & & Unstandardized Residual \\
\hline Normal Parameters ${ }^{\mathrm{a}, \mathrm{b}}$ & & 150 \\
\cline { 2 - 3 } & Mean &, 0000000 \\
\hline Most Extreme Differences & Std. Deviation & 37,44404332 \\
\cline { 2 - 3 } & Absolute &, 114 \\
\hline Test Statistic & Negitive & 114 \\
\hline Asymp. Sig. (2-tailed) & &,- 080 \\
\hline
\end{tabular}

a. Test distribution is Normal.

b. Calculated from data.

c. Lilliefors Significance Correction.

Source: Processed Data, 2020 
Based on the Kolmogorov Smirnov test results, investment (X1), liquidity (X2), profitability (X3), and dividend payout ratio policies (Y) did not meet the normal distribution requirements because the significant value was $0.000<0.05$. Thus, the regression model did not meet the classical assumption requirements.

\subsubsection{Normality Test after Transformation}

The good data must meet the normal distribution requirements so that if the data do not have a normal distribution, the data must undergo SQRT transformation. The normality test results after transformation can be seen in the following figure.

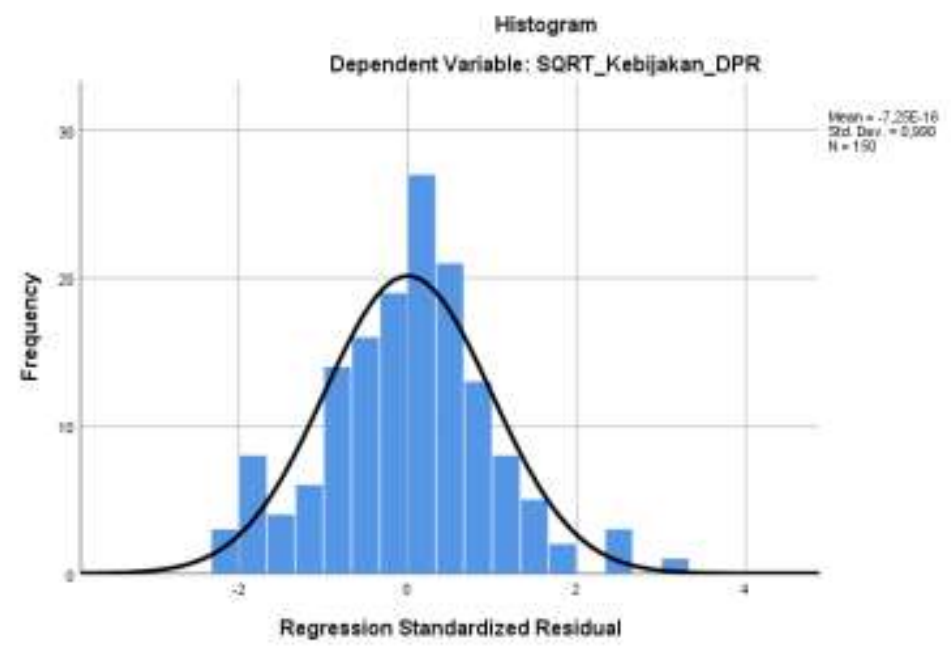

Figure 3. Histogram Normality Test After Transformation

Source: Processed Data, 2020

Based on the figure above, the curve lines are symmetrical, so it can be said that the data were normally distributed.

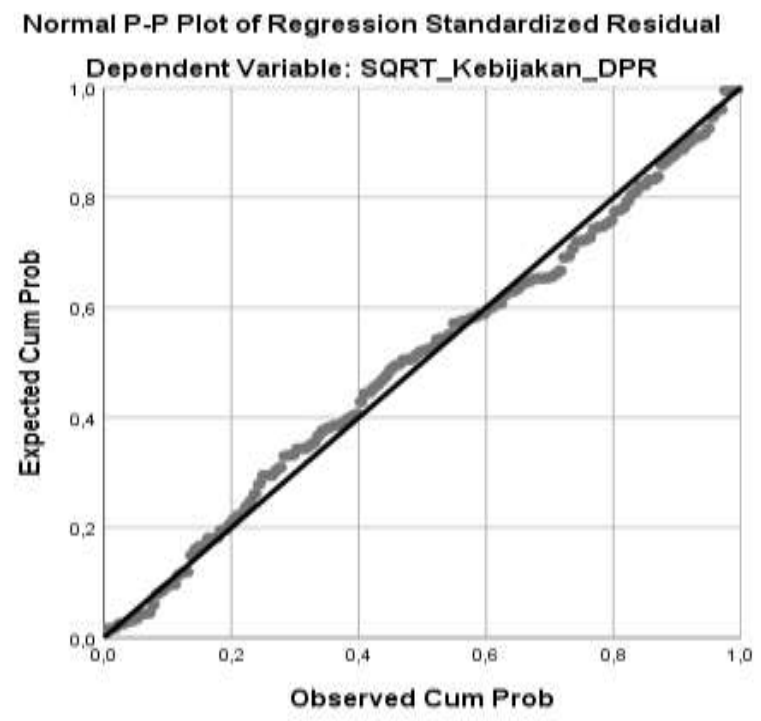

Figure 4. P-P Plot Normality Test Before Transformation Source: Processed Data, 2020

Based on the P-P Plot Normality Test graph, some of the points spread around the diagonal line, so it can be said that the data were normally distributed. 
Table 5 The Kolmogorov Smirnov Normality Test After Transformation

\section{One-Sample Kolmogorov-Smirnov Test}

\begin{tabular}{lll}
\hline $\mathrm{N}$ & & Unstandardized Residual \\
\hline Normal Parameters ${ }^{\mathrm{a}, \mathrm{b}}$ & Mean & 150 \\
\cline { 2 - 3 } & Std. Deviation &, 0000000 \\
\hline Most Extreme Differences & Absolute & 2,92741811 \\
\cline { 2 - 3 } & Positive &, 051 \\
\cline { 2 - 3 } & Negative &, 051 \\
\hline Test Statistic & &,- 048 \\
\hline Asymp. Sig. (2-tailed) & &, 051 \\
\hline
\end{tabular}

a. Test distribution is Normal.

b. Calculated from data.

c. Lilliefors Significance Correction.

d. This is a lower bound of the true significance.

Source: Processed Data, 2020

Based on the Kolmogorov Smirnov test results, investment (X1), liquidity (X2), profitability (X3), and dividend payout ratio policies (Y) met the normal distribution requirements because the significant value was $0.200>0.05$. Thus, the regression model met the classical assumption requirements.

\subsubsection{Multicollinearity Test Before Transformation}

The multicollinearity test aims to test whether the regression model has a correlation between the independent variables. A good regression model should not have a correlation between the independent variables. Multicollinearity is tested by looking at the tolerance value or the Variance Inflation Factor (VIF) value.

\section{Table 6. Multicollinearity Test Before Transformation}

\section{Coefficients}

\begin{tabular}{lll|l}
\multicolumn{1}{c}{ Model } & \multicolumn{2}{l}{$\begin{array}{l}\text { Collinearity Statistics } \\
\text { Tolerance }\end{array}$} & VIF \\
\hline 1 & Investment &, 786 & 1,272 \\
\cline { 2 - 4 } & Liquidity &, 968 & 1,033 \\
\cline { 2 - 4 } & Profitability &, 782 & 1,279 \\
\hline
\end{tabular}

a. Dependent Variable: _DPR

Source: Processed Data, 2020

The tolerance value limit is 0.1 and the VIF limit is 10 . If the tolerance value is $>0.1$ or VIF $<10$, there is no multicollinearity.The tolerance value of investment variable (X1) was $0.786>0.10$ while VIF value of investment variable $(X 1)$ was $1.272<10$. Thus, there was no regression between independent variables. The tolerance value of liquidity variable (X2) was $0.968>0.10$ while VIF value of liquidity variable $(\mathrm{X} 2)$ was $1.033<10$. Thus, there was no regression between independent variables. The tolerance value of the profitability variable $(\mathrm{X} 3)$ was $0.782>0.10$ while the VIF value of the profitability variable $(\mathrm{X} 3)$ was $1.279<10$. Thus, there was no regression between independent variables. 


\subsubsection{Multicollinearity Test After Transformation}

Table 7 Multicollinearity Test Before Transformation

\begin{tabular}{|c|c|c|c|}
\hline \multicolumn{4}{|c|}{ Coefficients $^{a}$} \\
\hline \multicolumn{2}{|l|}{ Model } & Tolerance & VIF \\
\hline \multirow[t]{3}{*}{1} & SQRT_Investment & ,769 & 1,300 \\
\hline & SQRT_Liquidity & ,983 & 1,017 \\
\hline & SQRT_Profitability & ,760 & 1,316 \\
\hline
\end{tabular}

a. Dependent Variable: SQRT__DPR

Source: Processed Data, 2020

The tolerance value limit is 0.1 and the VIF limit is 10 . If the tolerance value is $>0.1$ or VIF $<10$, there is no multicollinearity. The tolerance value of investment variable $(X 1)$ was $0.769>0.10$ while VIF value of investment variable $\left(X_{1}\right)$ was $1.300<10$. Thus, there was no regression between independent variables. The tolerance value of liquidity variable (X2) was $0.983>0.10$ while VIF value of liquidity variable (X2) was $1.017<10$. Thus, there was no regression between independent variables. The tolerance value of the profitability variable $(\mathrm{X} 3)$ was $0.760>0.10$ while VIF value of the profitability variable (X3) was $1.316<10$. Thus, there was no regression between independent variables.

\subsubsection{Autocorrelation Test Before Transformation}

The autocorrelation test aims to test whether a linear regression model has a correlation between confounding errors in period $t$ with errors in period t-1. Autocorrelation is the result of consecutive observations throughout the year relating to one another. This is often found in time series. This study used the Durbin Watson test to find autocorrelation problems.

Table 8. Autocorrelation Test Before Transformation

\begin{tabular}{|c|c|c|c|c|c|}
\hline \multicolumn{6}{|c|}{ Model Summary } \\
\hline Model & $\mathrm{R}$ & R Square & Adjusted R Square & $\begin{array}{l}\text { Std. Error of the } \\
\text { Estimate }\end{array}$ & Durbin-Watson \\
\hline 1 & $381^{a}$ & 145 & 128 & 37,826786 & 2,223 \\
\hline
\end{tabular}

a. Predictors: (Constant), Profitability, Liquidity, Investment

b. Dependent Variable: Kebijakan_DPR

Source: Processed Data, 2020

Thus, there was no positive and negative autocorrelation because du $<$ Dw $<4-$ du or $1.7741<2.223<2.2259$.

\section{Autocorrelation Test After Transformation}

Table 9. Autocorrelation Test Before Transformation

\begin{tabular}{|c|c|c|c|c|c|}
\hline \multicolumn{6}{|c|}{ Model Summary } \\
\hline Model & $\mathrm{R}$ & R Square & Adjusted R Square & $\begin{array}{l}\text { Std. Error of the } \\
\text { Estimate }\end{array}$ & Durbin-Watson \\
\hline 1 &, $369^{a}$ &, 136 & ,118 & 2,95734 & 2,300 \\
\hline
\end{tabular}

a. Predictors: (Constant), SQRT_Profitability, SQRT_Liquidity, SQRT_Investment

b. Dependent Variable: SQRT_DPR

Source: Processed Data, 2020

Thus, there was no negative autocorrelation because 4 - du $\leq \mathrm{d} \leq 4$ - $\mathrm{dl}$ or $2.259<2.300<2.3074$. 
Tabel 10. Runs Test

Runs Test

\begin{tabular}{ll} 
& Unstandardized Residual \\
\hline Test Value &, 15506 \\
\hline Cases $<$ Test Value & 75 \\
\hline Cases $>=$ Test Value & 75 \\
\hline Total Cases & 150 \\
\hline Number of Runs & 72 \\
\hline Z &,- 655 \\
\hline Asymp. Sig. (2-tailed) &, 512 \\
\hline
\end{tabular}

a. Median

Source: Processed Data, 2020

Based on the runs test results, the significance level was $0.512>0.05$. Thus, there was no autocorrelation.

\subsection{Heteroscedasticity Test Before Transformation}

A good regression model should not have heteroscedasticity. There are several ways to test for heteroscedasticity in the variance of the error terms for the regression model. This study used the chart (scatterplot diagram) method with the following premises: If the points form a certain regular pattern (wavy, widened, narrowed), there is heteroscedasticity, If the points spread above and below 0 on the $Y$ axis, there is no heteroscedasticity

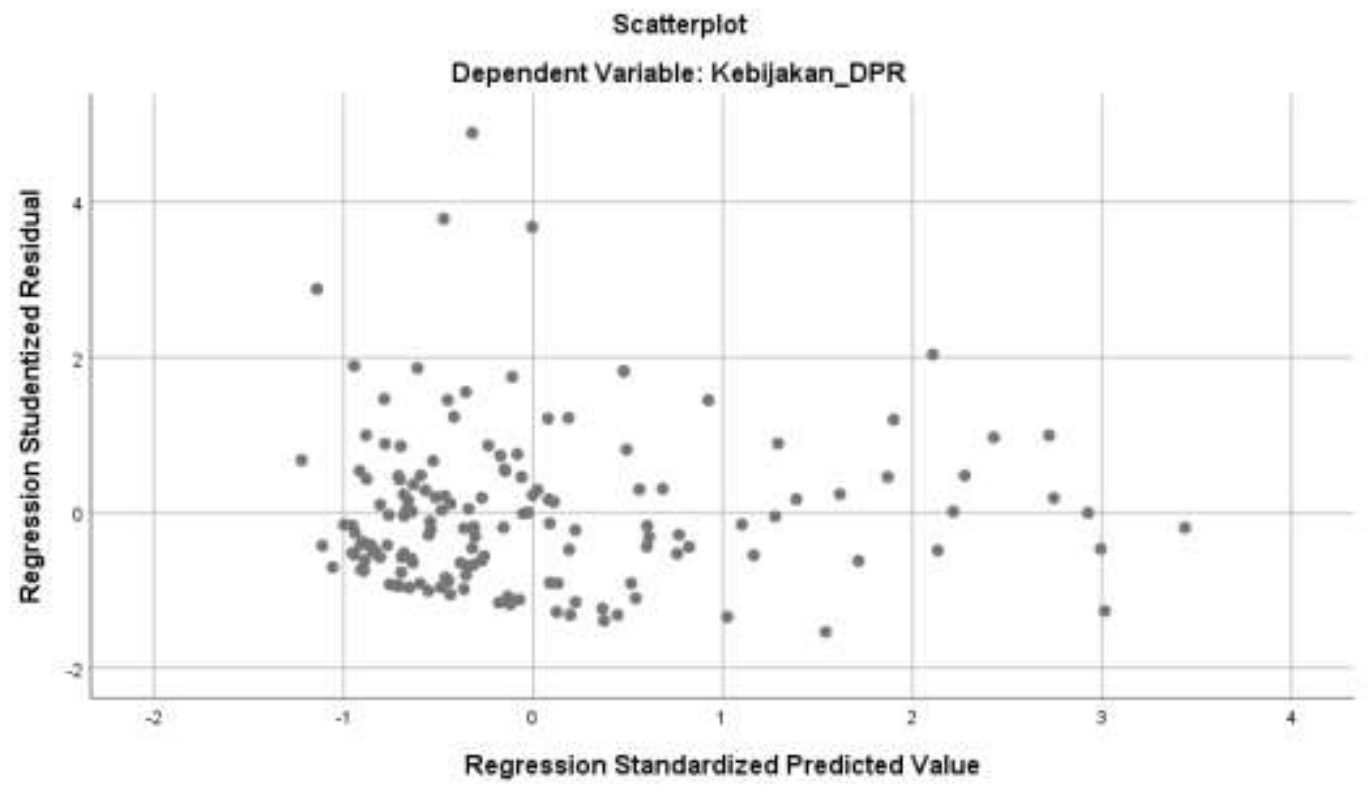

Figure 5. Heteroscedasticity Test Before Transformation

Source: Processed Data, 2020

Based on Figure 5, the points spread out randomly and are scattered both above and below the zero (0) on the Y-axis instead of in one place. Thus, there was no heteroscedasticity in the regression model.

\subsubsection{Heteroscedasticity Test After Transformation}

Before the transformation, the points did not randomly scatter, but after SQRT the transformation, the points spread out randomly and were scattered both above and below the zero $(0)$ on the $Y$-axis. The transformed scatterplot graph can be seen in the following figure: 


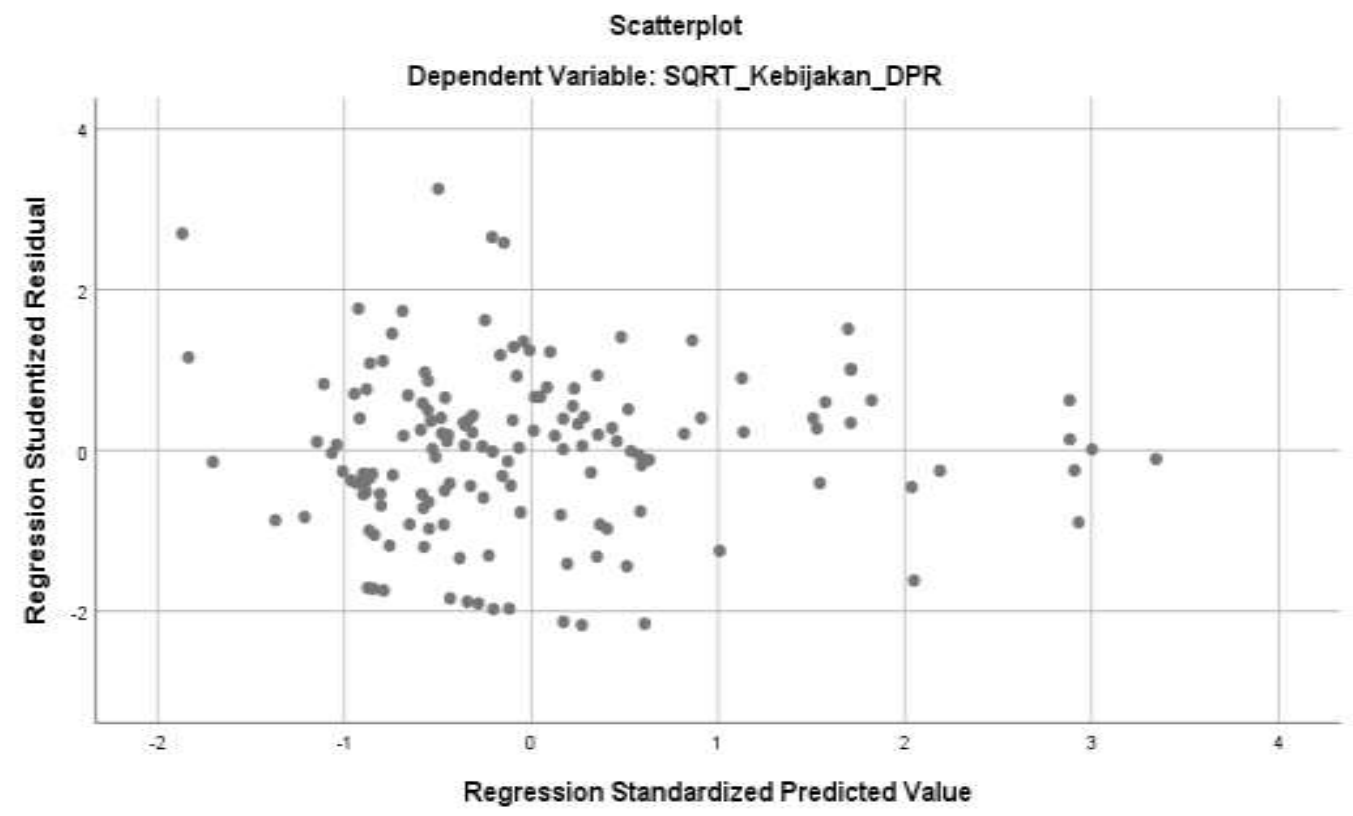

Figure 6 Heteroscedasticity Test After Transformation

Source: Processed Data, 2020

Based on the figure above, after the transformation, the points spread and did not converge in one place. Thus, there was no heteroscedasticity in the study data.

\subsubsection{Partial Hypothesis Testing}

The t-test aims to show the influence of one independent variable (investment, liquidity, and profitability) on the dependent variable (dividend payout ratio policies) partially. The t-test results can be seen in the following table.

\section{Table 11 t-test}

\section{Coefficients $^{\mathrm{a}}$}

\begin{tabular}{|c|c|c|c|c|c|c|}
\hline \multirow[b]{2}{*}{ Model } & & \multicolumn{2}{|c|}{ Unstandardized Coefficients } & \multirow{2}{*}{$\begin{array}{l}\text { Standardized } \\
\text { Coefficients } \\
\text { Beta }\end{array}$} & \multirow[b]{2}{*}{$\mathrm{t}$} & \multirow[b]{2}{*}{ Sig. } \\
\hline & & $\mathrm{B}$ & Std. Error & & & \\
\hline \multirow[t]{4}{*}{1} & (Constant) & 3,247 & 1,108 & & 2,930 &, 004 \\
\hline & SQRT_Investment &, 383 &, 150 & ,224 & 2,549 & ,012 \\
\hline & SQRT_Liquidity &, 328 & ,692 &, 037 & 474 & ,636 \\
\hline & SQRT_Profitability &, 483 & ,212 & ,201 & 2,276 &, 024 \\
\hline
\end{tabular}

a. Dependent Variable: SQRT_Kebijakan_DPR

Source: Processed Data, 2020

The t-table for 0.05 probability in degrees of freedom $(\mathrm{df}=146)$ was 1.97635 . Thus, the t-test results could explain the influence of each independent variable on the dependent variable as follows: Based on the results, t-calculation of investment variable was 2.549 with a significance level of $0.012<0.05$. Since t-calculation $>$ t-table or $2.549>1.97635$ with a significance value of $0.012<$ 0.05 , Ha was accepted, meaning that partially, investment had a significant and positive influence on dividend payout ratio policies of the 2015-2019 Indonesia Stock Exchange Listed LQ-45 companies. Based on the results, the t-calculation of the liquidity variable was 0.474 with a significance level of $0.636>0.05$. Since t-calculation $<$ t-table or $0.474<1.97635$ with a significance level of 0.636 $>0.05$, Ho was accepted meaning that partially, liquidity had no influence on dividend payout ratio policies of the 2015-2019 Indonesia Stock Exchange Listed LQ-45 companies. Based on the results, the t-calculation of the profitability variable was 2.276 with a significance level of $0.024<0.05$. Since t-calculation $>$ t-table or $2.276>1.97635$ with a significance value of $0.024<0.05$, Ha was accepted meaning that partially, profitability had a positive and significant influence on dividend payout ratio policies of the 2015-2019 Indonesia Stock Exchange Listed LQ-45 companies. 


\subsubsection{Simoultan Hypothesis Testing}

The F-test aims to show whether all the independent variables in the model have a simultaneous influence on the dependent variable. The F-test results can be seen in the following table.

Table 12. F test

$\begin{aligned} & \text { ANOVA } \\
& \text { Model }\end{aligned}$
\begin{tabular}{lll|l|l|l|l} 
Sum of Squares & df & Mean Square & F & Sig. \\
\hline 1 & Regression & 200,860 & 3 & 66,953 & 7,655 & \\
\cline { 2 - 8 } & Residual & 1276,897 & 146 & 8,746 & \\
\cline { 2 - 7 } & Total & 1477,757 & 149 & & \\
\hline
\end{tabular}

a. Dependent Variable: SQRT_Kebijakan_DPR

b. Predictors: (Constant), SQRT_Profitability, SQRT_Liquidity, SQRT_Investment

\section{Source: Processed Data, 2020}

Based on the simultaneous significance test ( $F$ test), the $F$ calculation was 7.655. At degrees of freedom $1(\mathrm{df} 1)=3$ and degrees of freedom $2(\mathrm{df} 2)=146$, the f-table at 0.05 significance level was 2.67. Since F-calculation $=7.655>$ F-table $=2.67$ with a significant value of $0.000<0.05$, Ha was accepted, meaning that, simultaneously, investment, liquidity, and profitability had a significant influence on the dividend payout ratio policies of the 2015 -2019 Indonesia Stock Exchange Listed LQ-45 companies.

\subsubsection{Coefficient of Determination}

The coefficient of determination aims to determine the ability of the model to explain the dependent variable.

\section{Table 13. Coefficient of Determination Test}

\begin{tabular}{|c|c|c|c|c|}
\hline \multicolumn{5}{|c|}{ Model Summary } \\
\hline Model & $\mathrm{R}$ & R Square & Adjusted R Square & Std. Error of the Estimate \\
\hline 1 &, $369^{a}$ & 136 & 118 & 2,95734 \\
\hline
\end{tabular}

a. Predictors: (Constant), SQRT_Profitability, SQRT_Liquidity, SQRT_Investment

Source: Processed Data, 2020

Based on the table above, the results of the determination coefficient test show the Adjusted $\mathrm{R}$ Square value of 0.118 , which means $11.8 \%$ of the variation in the dividend payout ratio policy variable, which can be explained by the independent variables investment, liquidity, and profitability, while the remaining $88.2 \%$ is explained by other independent variables which were not examined in this study for the example leverage ratio, growth and others.

\subsubsection{Descriptive Statistics}

Table 14. Descriptive Statistics

\begin{tabular}{ll|l|l|l|l} 
Descriptive Statistics & N & Minimum & Maximum & Mean & Std. Deviation \\
\hline Investment & 150 &, 055 & 105,067 & 8,36832 & 16,422084 \\
\hline Liquidity & 150 &, 606 & 6,567 & 2,14097 & 1,112657 \\
\hline Profitability & 150 &, 054 & 46,660 & 10,98634 & 9,667611 \\
\hline Kebijakan_DPR & 150 &, 000 & 224,796 & 46,36801 & 40,497506 \\
\hline Valid N (listwise) & 150 & & & & \\
\hline
\end{tabular}

Source: Processed Data, 2020

\section{Multiple Linear Regression Analysis}

The regression model used is as follows: 
Table 14.Multiple Linear Regression Analysis

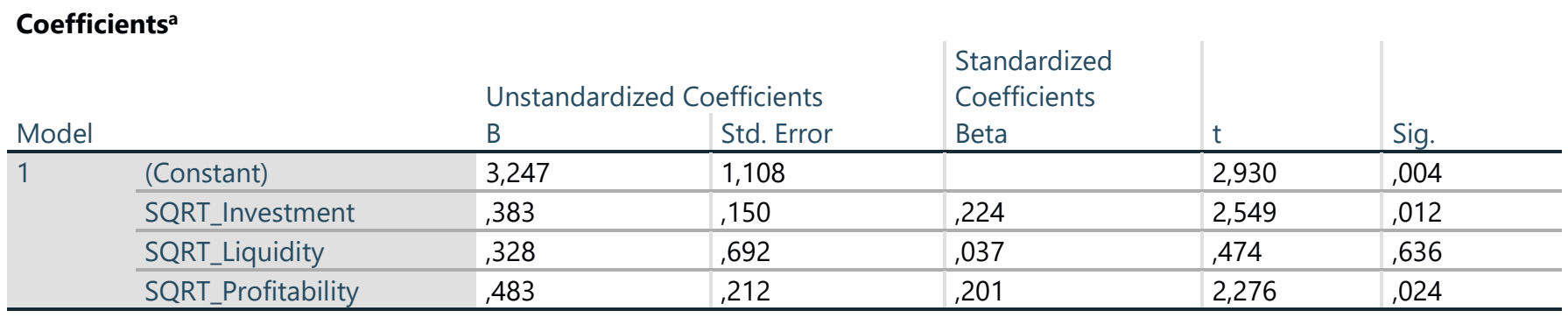

a. Dependent Variable: SQRT_Kebijakan_DPR

Source: Processed Data, 2020

$Y=3.247+0.383 X_{1}+0.328 X_{2}+0.483 X_{3}+e$

The multiple linear regression equation above can be explained as follows: The 3.247 units constant shows that if investment, liquidity, and profitability are zero, the dividend payout ratio policies will increase by 3.247 units. The 0.383 unit regression coefficient of investment with a positive value shows that for every 1 unit increase in investment, it causes an 0.383 unit increase of the dividend payout ratio policies. The 0.328 unit regression coefficient of liquidity with a positive value shows that for every 1 unit increase, it causes an 0.328 unit increase of the dividend payout ratio policies. The 0.483 unit regression coefficient of profitability with a positive value shows that for every 1 unit increase, it causes an 0.483 unit increase of the dividend payout ratio policies

\subsection{Discussion}

\subsubsection{The Influence of Investment on Dividend Payout Ratio Policies}

Since $\mathrm{t}$-calculation $>\mathrm{t}$-table or $2.549>1.97635, \mathrm{H} 1$ was accepted because partially, investment had a significant and positive influence on the dividend payout ratio policies of the 2015-2019 Indonesia Stock Exchange Listed LQ-45 companies. This shows that every increase in investment will cause an increase in the dividend payout ratio policies. Thus, the higher the investment decision made by the company, the more likely the company will pay dividends. This is in line with a study by Purnamasari, et al. (2019), which shows that investment opportunities had a positive and significant influence on dividend policies.

\subsubsection{The influence of Liquidity on Dividend Payout Ratio Policies}

Since t-calculation < t-table or $0.474<1.97635, \mathrm{H} 2$ was rejected because liquidity had no significant influence on dividend payout ratio policies of the 2015-2019 Indonesia Stock Exchange Listed LQ-45 companies. This shows that the higher the liquidity value, the more companies are able to pay for all liabilities. In fact, even though companies have a high liquidity value, not all companies are able to pay increasing dividends from year to year to investors. This is not in line with a study by Sari and Suryantini (2019) shows that liquidity had a positive and significant influence on the dividend payout ratio.

\subsubsection{The Influence of Profitability on Dividend Payout Ratio Policies}

Since t-calculation > t-table or $2.276>1.97635, \mathrm{H} 1$ was accepted because, partially, profitability had a positive and significant influence on dividend payout ratio policies of the 2015-2019 Indonesia Stock Exchange Listed LQ-45. This shows that every increase in profitability will cause an increase in the dividend payout ratio policies. Thus, the higher the profitability, the higher the dividends. This is in line with a study by Sari and Suryantini (2019) shows that profitability had a positive and significant influence on the dividend payout ratio.

\subsubsection{The Influence of Investment, Liquidity, and Profitability on Dividend Payout Ratio Policies}

Based on simultaneous test using F test, since F-calculation> F-table and significance level $<0.05$ namely $7.655>2.67$ and 0.000 $<0.05$, H4 was accepted because simultaneously, investment, liquidity, and profitability had a significant influence on dividend payout ratio policies of the 2015-2019 Indonesia Stock Exchange Listed LQ-45 companies. Thus, investment, liquidity, and profitability can be considered by shareholders in investing in shares to obtain a high dividend payout. Simultaneously, investment, liquidity, and profitability had an $11.8 \%$ influence on the dividend payout ratio policies while the remaining $88.2 \%$ were explained by other variables such as leverage ratio, growth, and others.

\section{Conclusion}

Based on the results, it can be concluded that Partially, investment had a positive and significant influence on dividend payout ratio policies of the 2015-2019 Indonesia Stock Exchange Listed LQ-45 companies with $t_{\text {-calculation }} 2.549>t_{\text {tabel }} 1.97635$ and significance level of $0.012<0.05$. Partially, liquidity had no influence on dividend payout ratio policies of the 2015-2019 Indonesia Stock Exchange Listed LQ-45 companies with tcalculation $0.474<\mathrm{t}_{\text {tabel }} 1,97635$ and significance level of $0.636>0.05$. Partially, 
profitability had a positive and significant influence on dividend payout ratio policies of the 2015-2019 Indonesia Stock Exchange Listed LQ-45 companies with tcalculation $2.276>t_{\text {table }} 1.97635$ and significance level of $0.024<0.05$. Simultaneously, investment, liquidity, and profitability had an influence on dividend payout ratio policies of the 2015-2019 Indonesia Stock Exchange Listed LQ-45 companies with $11.8 \%$ Adjusted $R$ Square showing the influence of the independent variable on the dependent variable while the remaining $88.2 \%$ were influenced by other variables such as leverage ratio, growth, and others.

\section{Recommendation}

Based on the results, there are several recommendations in order for the investment to increasingly affect the dividend payout ratio policies. LQ-45 companies must carry out careful planning before determining investment because investment requires a large number of funds. In order for liquidity to increasingly affect the dividend payout ratio policies, LQ-45 companies must pay attention to the level of cash adequacy to meet current liabilities properly. In order for profitability to increasingly affect the dividend payout ratio policies, LQ-45 companies must increase product sales by utilizing technology and information systems. With regard to dividend payout ratio policies, it is recommended that LQ-45 companies be able to pay the dividend to shareholders in a stable manner because shareholders certainly really want a dividend payout from their invested capital.

\section{References}

[1] Ghozali, I. (2016) Application of Multivariate Analysis with SPSS Program 23. 8th Edition. Semarang: Diponegoro University Publishing Agency.

[2] Harahap, S. (2019). Critical Analysis of Financial Statements. 10th edition. Jakarta: PT Raja Grafindo Persada.

[3] Harry. (2017). Study of Accounting Research. Jakarta: PT. Grasindo.

[4] Horne, J. C. Van \& John M. W. (2016). Principles of Financial Management. 4th Printing 13th Edition. Jakarta: Publisher Salemba Empat.

[5] Jusuf, J. (2016). Credit Analysis for Account Officers. 11th printing. Jakarta: PT. Main Library Gramedia.

[6] Kariyoto M. (2017). Analysis of Financial Statements. 1st printing. UB Press. Poor.

[7] Kasmir W, (2015). Analysis of Financial Statements. 8th printing. Jakarta: Publisher PT. King Grafindo Persada.

[8] Mulyaman, S., (2015). Financial Management. 1st printing. Bandung: CV. Faithful Library.

[9] Murhadi, W. R. (2018). Analysis of Financial Statements: Projections and Stock Valuation. 3rd printing. Jakarta: Publisher Salemba Empat.

[10] Prihadi, T. (2019). Analysis of Theory Financial Statements and Applications. 2nd printing. Jakarta: PT. Gramedia Pustaka Utama.

[11] Rambe, M. (2015). Financial Management. Bandung: Media Library

[12] Sudana, I. M. (2015). Corporate Financial Management: Theory \& Practice. 2nd Edition. Jakarta: Erlangga Publisher.

[13] Sugiyono K. (2017). Qualitative Quantitative Research Methods and R\&D. 26th printing. Bandung: PT Alfabeta.

[14] Purnamasari, I. (2019). The Influence of Investment Opportunities and Debt Policy on Dividend Policy. Journal of Accounting and Financial Research. 7(1)

[15] Sari, N. P. and Ni P. S. S (2019). The Effect of Profitability, Liquidity, and Growth Rate on Dividend Policy in Manufacturing Companies. EJournal of Management, 8(7), 2019:4559-4588. ISSN: 2302-8912. DOI: https://doi.org/10.24843/EJMUNUD.2019.v08.i07.p20

[16] Sulaiman, H., and Sumani. (2016). Analysis of the Effect of Liquidity, Leverage, Activity, Profitability, and Growth on the Dividend Policy of Issuers Listed on the LQ-45 Index for the Period 2011-2013. Journal of Management, 3(2) Pages 179-197. 